\title{
Secondary Hypertriglyceridemia Causing Recurrent Acute Pancreatitis with Normal Pancreatic Enzymes
}

\author{
Prabhat Kumar, Anindya Ghosh'1, Nitin Sinha', Rajinder Singh Tonk ${ }^{1}$ \\ Department of Medicine, All India Institute of Medical Sciences, ${ }^{1}$ Department of Medicine, PGIMER and Dr. RML Hospital, New Delhi, India
}

\section{Abstract}

Hypertriglyceridemia (HTG) is the third leading cause of acute pancreatitis (APs) worldwide which is invariably associated with elevated pancreatic enzyme levels. We present a case of HTG-induced recurrent AP with normal serum amylase and lipase levels in a patient of Syndrome Z.

Keywords: Insulin, statins, Syndrome Z

\section{INTRODUCTION}

Acute pancreatitis (AP) is a potentially life-threatening inflammation of the pancreas with myriad causes. Incidence is $30-80 / 100,000$ population and diagnosis is made using clinical, biochemical, and imaging criteria. Of these, the biochemical criteria require an elevation of serum lipase and/or amylase levels to $>3$ times upper limit of normal. AP with normal serum amylase and lipase levels is rare with only few reported cases so far. Hypertriglyceridemia (HTG)-induced recurrent acute pancreatitis (RAP) is uncommon, and its occurrence with normal pancreatic enzyme levels has not been reported so far.

\section{Case Report}

A 58-year-old man presented with complaints of severe dull aching upper abdominal pain which was radiating to the back for 1 day with two episodes of nonbilious vomiting. He further told that he was having similar episodes of abdominal pain every year for the last 8 years, for which he needed hospitalization. He was a diagnosed case of type 2 diabetes mellitus (for 25 years), hypertension, coronary artery disease, dyslipidemia, and obstructive sleep apnea (OSA). He was on Insulin therapy for diabetes along with antiplatelets, beta-blockers, angiotensin-converting enzyme inhibitors, trimetazidine, statins (rosuvastatin $20 \mathrm{mg}$ ), and fibrates (fenofibrate $160 \mathrm{mg}$ ). He never adhered to his prescribed diabetic diet regimen and often used to miss his drugs too. On examination, he had body mass index of $37 \mathrm{~kg} / \mathrm{m}^{2}$ and

\begin{tabular}{|l|l|}
\hline \multicolumn{3}{|c|}{ Access this article online } \\
\hline Quick Response Code: & Website: \\
& www.ijccm.org \\
\hline
\end{tabular}

had severe epigastric tenderness with sluggish bowel sounds. Fundus examination showed nonproliferative diabetic retinopathy. A possibility of AP was kept, and following investigations were done.

His serum was lipemic. Blood investigations showed total leukocyte count-16,000/cu mm (N-88\%, L-11\%), blood sugar of $221 \mathrm{mg} / \mathrm{dl}$, grossly deranged lipid profile with normal renal and liver function tests [Table 1]. Serum amylase, lipase levels, thyroid function test, and serum electrolytes were normal. Urinalysis showed proteinuria (1+) and was negative for ketone bodies. Ultrasonography of the abdomen showed bulky pancreas, which was suggestive of AP.

He was kept nil orally, and intravenous fluids were administered along with subcutaneous insulin therapy. He was allowed soft diet after $48 \mathrm{~h}$ of admission. We went through his older documents in view of significant history of recurrent admissions for similar complaints. He had multiple admissions for HTG-induced AP, but his serum amylase and lipase level always remained normal during the episode. His diabetic status was never controlled, and even during his present admission, he had glycosylated hemoglobin level

Address for correspondence: Dr. Prabhat Kumar, Department of Medicine, All India Institute of Medical Sciences, Third Floor, Teaching Block, New Delhi - 110 029, India. E-mail: drkumar.prabhat@gmail.com

This is an open access journal, and articles are distributed under the terms of the Creative Commons Attribution-NonCommercial-ShareAlike 4.0 License, which allows others to remix, tweak, and build upon the work non-commercially, as long as appropriate credit is given and the new creations are licensed under the identical terms.

For reprints contact: reprints@medknow.com

How to cite this article: Kumar P, Ghosh A, Sinha N, Tonk RS. Secondary hypertriglyceridemia causing recurrent acute pancreatitis with normal pancreatic enzymes. Indian J Crit Care Med 2018;22:381-3. 


\begin{tabular}{|c|c|c|c|}
\hline & Normal & Day 1 & Day 4 \\
\hline Triglyceride & $35-150 \mathrm{mg} / \mathrm{dl}$ & 1078 & 574 \\
\hline $\mathrm{HDL}$ & $35-70 \mathrm{mg} / \mathrm{dl}$ & 19 & 28 \\
\hline LDL & $<150 \mathrm{mg} / \mathrm{dl}$ & 72 & 60 \\
\hline VLDL & $15-35 \mathrm{mg} / \mathrm{dl}$ & 216 & 120 \\
\hline Amylase & 30-110 IU/1 & 77 & 90 \\
\hline Lipase & 20-200 IU/1 & 54 & 65 \\
\hline
\end{tabular}

LDL: Low-density lipoprotein; HDL: High-density lipoprotein;

VLDL: Very low-density lipoprotein

of $9.8 \%$. A contrast-enhanced computed tomography (CT) done on the $4^{\text {th }}$ day of admission showed acute interstitial pancreatitis with a modified CT severity index 2 and without any evidence of chronic pancreatitis [Figure 1]. Magnetic resonance cholangiopancreatography showed normal biliary tree and pancreatic ductal system. Endoscopic ultrasound done previously did not reveal any abnormality.

A family screening among first-degree relatives for familial dyslipidemia was negative, and serum ApoC-II was normal. A final diagnosis of Syndrome Z-associated secondary HTG causing RAP was made. He was advised strict 1200 calorie diabetic diet, regular physical activity, and counseled regarding strict adherence to his prescribed medications. His insulin dose was optimized and other drugs for various comorbidities were continued. Dose of rosuvastatin was increased to $40 \mathrm{mg}$, fibrates were continued, and oral saroglitazar $4 \mathrm{mg}$ once daily was also added. He has not developed any new episode of APs in 1-year follow-up, and his latest triglyceride (TG) level was $412 \mathrm{mg} / \mathrm{dl}$.

\section{Discussion}

Lipase level is more sensitive and specific than amylase for diagnosis of AP and normal lipase levels in AP, is a rare entity. There can be two possible explanations for AP with normal lipase levels. One includes decreased enzyme source which might occur with RAP during the transition to chronic pancreatitis. This intermediate stage of chronic pancreatitis poses a diagnostic challenge as there is no imaging evidence of chronic pancreatitis. This possibility was ruled out in our patient as he had normal lipase levels each time dating back to the first episode of pancreatitis. The second possibility is interference with the colorimetric assay that uses the cleavage of a chromogenic substrate by lipase to form a red dye whose intensity is proportional to lipase activity, measured photometrically. This assay technique requires sample turbidity to be taken into consideration, especially in lipemic serum samples. Thus, the turbidity of the serum due to HTG can lead to spuriously low lipase levels. ${ }^{[1]} \mathrm{A}$ total of nine patients with AP and normal serum lipase levels on initial presentation and during follow-up have been reported so far. Most of these patients had diabetes mellitus, followed by gallbladder stones. ${ }^{[2-6]}$ However, no case of RAP with normal lipase and amylase levels have been reported yet.

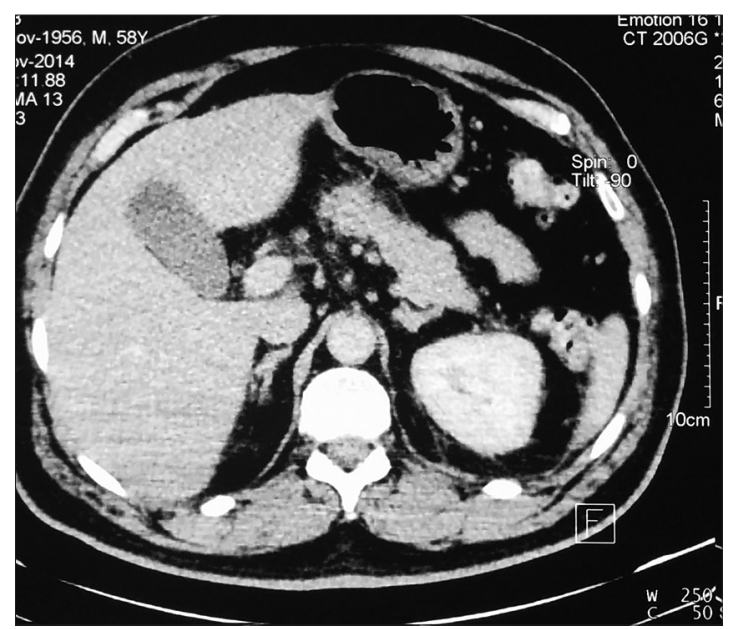

Figure 1: Computed tomography abdomen showing acute interstitial pancreatitis

RAP is defined as $\geq 2$ attacks of AP without any evidence of chronic pancreatitis. Investigations usually reveal an etiology in $60 \%-70 \%$ cases while $20 \%-30 \%$ cases remain idiopathic (known as idiopathic RAP [IRAP]). Of the known causes of AP, alcohol, and gallstones constitute the majority. The causes of IRAP discovered on subsequent investigations include microlithiasis, sphincter of Oddi dysfunction, pancreas divisum, vascular and metabolic causes like HTG. ${ }^{[7]}$

HTG is the third-most common and possibly an often underestimated and missed cause of AP, accounting for $1 \%-7 \%$ of cases. It can be familial as in Type I, Type IV, and Type V hyperlipidemias. It is, however, more commonly associated with risk factors such as obesity, diabetes, pregnancy, alcohol, estrogen replacement, and hypothyroidism. The mechanism of HTG-induced pancreatitis is chylomicron induced stasis of pancreatic microcirculation, which causes trypsinogen activation and pancreatic autodigestion. ${ }^{[8]}$ The management HTG induced AP includes conventional treatment for AP and specific therapy for lowering TG levels below $500 \mathrm{mg} / \mathrm{dl}$. Insulin is the preferred treatment here, and it acts by increasing synthesis of lipoprotein lipase levels. Plasmapheresis, though effective is an expensive option and is not commonly used. ${ }^{[8]}$ Lipid-lowering agents can be added as an adjuvant therapy.

Syndrome $\mathrm{Z}$ represents the interaction of OSA with vascular risk factors and includes the quartet of hypertension, central obesity, insulin resistance, and hyperlipidemia. ${ }^{[9]}$ Our patient had all the components of the syndrome including secondary HTG.

\section{Conclusion}

A normal lipase level can, by no means rule out AP. Diagnosis can pose a significant challenge in cases with chronic pancreatitis and in conditions like HTG, where photometrically derived assays can give faulty result. 


\section{Acknowledgment}

The manuscript has been read and approved by all the authors and author believes that the manuscript represents honest work.

\section{Declaration of patient consent}

The authors certify that they have obtained all appropriate patient consent forms. In the form the patient(s) has/have given his/her/their consent for his/her/their images and other clinical information to be reported in the journal. The patients understand that their names and initials will not be published and due efforts will be made to conceal their identity, but anonymity cannot be guaranteed.

\section{Financial support and sponsorship}

Nil.

\section{Conflicts of interest}

There are no conflicts of interest.

\section{References}

1. Twomey PJ, Don-Wauchope AC, McCullough D. Unreliability of triglyceride measurement to predict turbidity induced interference.
J Clin Pathol 2003;56:861-2.

2. Cartier T, Sogni P, Perruche F, Meyniard O, Claessens YE, Dhainaut JF, et al. Normal lipase serum level in acute pancreatitis: A case report. Emerg Med J 2006;23:701-2.

3. Shah AM, Eddi R, Kothari ST, Maksoud C, DiGiacomo WS, Baddoura $\mathrm{W}$, et al. Acute pancreatitis with normal serum lipase: A case series. JOP 2010;11:369-72.

4. Deschasse G, Tolsma V, Bioteau C, Couturier P, Gavazzi G. Acute pancreatitis with normal lipase in an 80-year-old man. J Am Geriatr Soc 2011;59:1542-3.

5. Mayersak JS, Viviano CJ, Babiarz JW. Computed axial tomography pancreatitis: An atypical asymptomatic postoperative disease without serum or urinary enzyme evaluation. Wis Med J 1997;96:25-8.

6. Khan FY, Matar I. Chylous ascites secondary to hyperlipidemic pancreatitis with normal serum amylase and lipase. World J Gastroenterol 2007; 13:480-2.

7. Kedia S, Dhingra R, Garg PK. Recurrent acute pancreatitis: An approach to diagnosis and management. Trop Gastroenterol 2013;34:123-35.

8. Mikhail N, Trivedi K, Page C, Wali S, Cope D. Treatment of severe hypertriglyceridemia in nondiabetic patients with insulin. Am J Emerg Med 2005;23:415-7.

9. Wilcox I, McNamara SG, Collins FL, Grunstein RR, Sullivan CE. "Syndrome Z": The interaction of sleep apnoea, vascular risk factors and heart disease. Thorax 1998;53 Suppl 3:S25-8. 